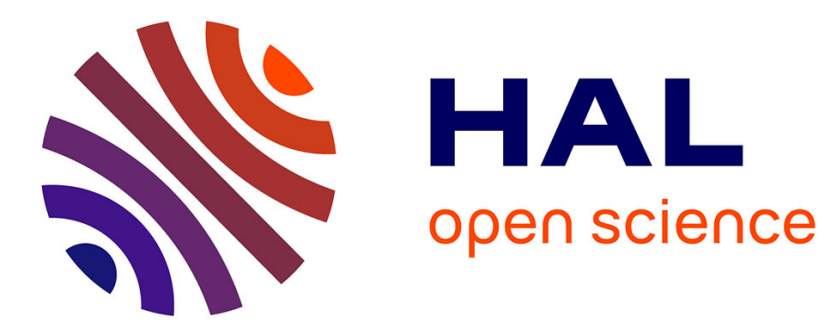

\title{
Modification of the Atmospheric Polonium 210 to Lead 210 Ratio by Volcanic Emissions
}

\author{
G. Lambert, A. Buisson, J. Sanak, B. Ardouin
}

\section{To cite this version:}

G. Lambert, A. Buisson, J. Sanak, B. Ardouin. Modification of the Atmospheric Polonium 210 to Lead 210 Ratio by Volcanic Emissions. Journal of Geophysical Research, 1979, 84 (C11), pp.6980. 10.1029/JC084iC11p06980 . hal-03408900

\section{HAL Id: hal-03408900 https://hal.science/hal-03408900}

Submitted on 29 Oct 2021

HAL is a multi-disciplinary open access archive for the deposit and dissemination of scientific research documents, whether they are published or not. The documents may come from teaching and research institutions in France or abroad, or from public or private research centers.
L'archive ouverte pluridisciplinaire HAL, est destinée au dépôt et à la diffusion de documents scientifiques de niveau recherche, publiés ou non, émanant des établissements d'enseignement et de recherche français ou étrangers, des laboratoires publics ou privés. 


\title{
Modification of the Atmospheric Polonium 210 to Lead 210 Ratio by Volcanic Emissions
}

\author{
G. Lambert,' A. Buisson, J. Sanak, and B. Ardouin
}

Centre des Faibles Radioactivités, Centre National de la Recherche Scientifique F91190, Gif-sur-Yvette, France

\begin{abstract}
Volcanic gases are very rich in long-lived radon daughters, especially in ${ }^{210}$ Po. Thus more than $50 \times$ $10^{3} \mathrm{Ci}$ per year of ${ }^{210} \mathrm{Po}$ are injected into the troposphere by a normal volcanic activity, and more than 1 $\times 10^{3} \mathrm{Ci}$ per year into the stratosphere by volcanic explosions. These fluxes should account for one half of the ${ }^{210} \mathrm{Po}$ content in both of these reservoirs. On the contrary the volcanic sources of ${ }^{222} \mathrm{Rn}$ and ${ }^{210} \mathrm{~Pb}$ are generally negligible with regard to the soil production. This new result could explain most of the discrepancies observed by comparing the activity ratios of the different radon daughters, including the existence of ${ }^{210} \mathrm{Po} /{ }^{210} \mathrm{~Pb}$ figures superior to one (overequilibriums). Stratospheric aerosol residence times calculated on this basis are found to be shorter than the previous figures.
\end{abstract}

Radon 222 and its decay products have been considerably utilized in atmospheric studies [Jacobi and Andre, 1963; Lambert and Nezami, 1965; Karol, 1970; Turekian et al., 1977]. One reason for this is that the disintegration of the atmospheric gaseous radon is followed, within 1 hour, by a series of longlived radioactive daughters, quickly fixed on atmospheric aerosol particles:

$$
\begin{aligned}
& { }_{86}^{222} \mathrm{Rn} \rightarrow \underset{82}{210} \mathrm{~Pb} \stackrel{\beta}{\rightarrow} \underset{83}{210} \mathrm{Bi} \stackrel{\beta}{\rightarrow}{ }_{84}^{210} \mathrm{Po} \stackrel{a}{\rightarrow}{ }_{82}^{206} \mathrm{~Pb} \\
& \begin{array}{cccc}
3.8 \mathrm{~d} & 20 \mathrm{y} & 5 \mathrm{~d} & 138 \mathrm{~d} \\
\leftarrow \text { gas } \rightarrow & \leftarrow \text { aerosols } & \rightarrow & \text { stable }
\end{array}
\end{aligned}
$$

Assuming that the aerosols are removed from the atmosphere by a first-order process, it is possible to define a scavenging constant $\lambda_{s}$, similar to the radioactive constants $\lambda_{\mathrm{Rn}}$, $\lambda_{\mathrm{Pb}}$, etc. Therefore in a closed reservoir the classical equations of the radioactive equilibrium are modified and lead to the following expressions [Burton and Stewart, 1960]:

$$
\frac{{ }^{210} \mathrm{~Pb} \text { activity }}{{ }^{222} \mathrm{Rn} \text { activity }}=\frac{\lambda_{\mathrm{Pb}}}{\lambda_{\mathrm{Pb}}+\lambda_{s}}=\frac{\lambda_{\mathrm{Pb}}}{\lambda_{S}}
$$

since $\lambda_{\mathrm{Pb}}$ is about $10^{3}$ times smaller than $\lambda_{s}$, as shown later.

$$
\frac{{ }^{210} \mathrm{Po} \text { activity }}{{ }^{210} \mathrm{~Pb} \text { activity }}=\frac{\lambda_{\mathrm{Bi}} \lambda_{\mathrm{Po}}}{\left(\lambda_{\mathrm{Bi}}+\lambda_{s}\right)\left(\lambda_{\mathrm{Po}}+\lambda_{s}\right)}
$$

It is meaningless to compare directly the concentrations of ${ }^{222} \mathrm{Rn}$ and of its long-lived decay products measured just above the continents, since the vertical gradients due to atmospheric mixing processes are very different. However, far from the radon sources, it is possible to use the ${ }^{210} \mathrm{Po} /{ }^{210} \mathrm{~Pb}$ activity ratio to obtain a value of $\lambda_{s}$ if all of ${ }^{210}$ Po were directly produced from ${ }^{210} \mathrm{~Pb}$.

Nevertheless, according to Moore et al. [1973], the injection from the stratosphere into the troposphere of lead and polonium 210 approximately in radioactive equilibrium can be significant and results in the overestimating of the aerosol residence time.

Other sources of ${ }^{210} \mathrm{Po}$ such as soil particles and vegetal debris have also been considered by Marenco and Fontan [1972],

\footnotetext{
' Also at the Université de Picardie, St. Quentin, France.

Copyright (C) 1979 by the American Geophysical Union.
}

who concluded nevertheless that they were of very small importance, and by Poet et al. [1972], who assumed that they could play a significant role.

\section{SUbANTARCTIC ATMOSPHERE}

Over the sub-Antarctic ocean the atmospheric concentrations are typically $1.2 \times 10^{-12} \mathrm{Ci} / \mathrm{m}^{3}$ for ${ }^{222} \mathrm{Rn}$ and $0.3 \times 10^{-15}$ $\mathrm{Ci} / \mathrm{m}^{3}$ for ${ }^{210} \mathrm{~Pb}$ [Lambert et al., 1966, 1972; Sanak et al., 1978] which gives $\lambda_{s} \simeq 3.7 \times 10^{-1} \mathrm{~d}^{-1}$ and a corresponding aerosol half-life of about $1.9 \mathrm{~d}$. This figure of $\lambda_{s}$ should give for the ${ }^{210} \mathrm{Po} /{ }^{210} \mathrm{~Pb}$ ratio $3.6 \times 10^{-3}$ instead of an average figure actually observed of about 0.5 , i.e., 140 times more.

Lambert et al. [1966] have deduced, from the latitudinal repartition of radioactive aerosols, that in the southern hemisphere ${ }^{210} \mathrm{~Pb}$ has essentially a stratospheric origin, even at low altitude. However, this effect should be particularly weak in the subantarctic area, which is known to be, on the opposite, characterized by a very low injection rate of nuclear test stratospheric debris. Moreover, in about $22 \%$ of the samples, the activity of ${ }^{210} \mathrm{Po}$ has been found higher than that of ${ }^{210} \mathrm{~Pb}$ (overequilibrium).

Consequently, it seems necessary to admit the existence, in the lower atmosphere, of polonium 210 sources independent of the atmospheric radon. Turekian et al. [1974] have observed that the ${ }^{210} \mathrm{Po} /{ }^{210} \mathrm{~Pb}$ activity ratio, in zooplankton is about 20 30. Consequently, a flux could be expected from the sea surface to the atmosphere, of particles especially enriched in ${ }^{210} \mathrm{Po}$ relative to ${ }^{210} \mathrm{~Pb}$. As mentioned in a previous paper [Lambert et al., 1974], it has been pointed out that this effect was able to account for a limited overequilibrium ${ }^{210} \mathrm{Po} /{ }^{210} \mathrm{~Pb}$ in oceanic air masses.

A first approach of this problem could result of a comparison of the ${ }^{210} \mathrm{Po}$ to organic carbon ratios in seawater, in zooplankton and in marine atmospheric particulate matter. On one hand, Nozaki and Tsunogai [1976] and Nozaki et al. [1976] have found about $10 \mathrm{dpm}$ of ${ }^{210} \mathrm{Po}$ per $100 \mathrm{~kg}$ of seawater; Bacon et al. [1976] have found very similar results for the dissolved phase in superficial water and about $1 \mathrm{dpm} / 100$ kg in the particulate materials. On the other hand, a particulate organic carbon concentration of 1 to $5 \times 10^{-2} \mathrm{~g} / 100 \mathrm{~kg}$ can be inferred from the chlorophyl measures by $G$. Jacque (private communication, 1978). Thus an activity of about 20 $100 \mathrm{dpm} / \mathrm{g}$ of carbon could be a good order of magnitude for the seawater particulate phase. Turekian et al. [1974] have also found a ${ }^{210}$ Po concentration of $2-200 \mathrm{dpm} / \mathrm{g}$ of dry zooplank- 
ton in agreement with Beasley [1973], who has measured ${ }^{210} \mathrm{Po}$ concentrations comprised between 2 and $20 \mathrm{dpm} / \mathrm{g}$ dry in different kinds of zooplankton. With $0.3 \mathrm{~g}$ of carbon per gram of zoo plankton, these figures correspond to $6-60 \mathrm{dpm} / \mathrm{g}$ of carbon and exceptionally up to $600 \mathrm{dpm} / \mathrm{g}$.

It seems therefore reasonable to admit for ${ }^{210} \mathrm{Po}$ an average concentration of the order of $40 \mathrm{dpm} / \mathrm{g}$, that is, $20 \mathrm{pCi} / \mathrm{g}$ of carbon.

In the marine atmosphere, organic carbon concentrations of $0.2-0.8 \mu \mathrm{g} / \mathrm{m}^{3}$ have been observed by Hoffman and Duce [1977]. Barger and Garrett [1970] have reported some figures reaching $6.3 \mu \mathrm{g} / \mathrm{m}^{3}$ for a wind velocity of $8.5 \mathrm{~m} / \mathrm{s}$, which is the right order of magnitude for subantarctic areas. Consequently, a concentration of $2-8 \mu \mathrm{g} / \mathrm{m}^{3}$ seems to be a good evaluation of the range of values in this region.

Finally, an atmospheric ${ }^{210}$ Po concentration of 0.04 to 0.16 $\times 10^{-15} \mathrm{Ci} / \mathrm{m}^{3}$ could be attributed to the marine source over the subantarctic ocean where the values measured are generally between 0 and $0.5 \times 10^{-15} \mathrm{Ci} / \mathrm{m}^{3}$.

Figure 1 shows the histograms of the ${ }^{210} \mathrm{~Pb}$ aerosol concentrations at Kerguelen Island $\left(49^{\circ} \mathrm{S}\right)$ for all data and for different figures of the ${ }^{210} \mathrm{Po} /{ }^{210} \mathrm{~Pb}$ ratio. It is clear, by comparing Figures $1 b$ and $l c$, that high values of this ratio $(>0.5)$ can only be obtained for low ${ }^{210} \mathrm{~Pb}$ concentrations $\left(<1 \times 10^{-15} \mathrm{Ci}\right.$ / $\mathrm{m}^{3}$ ) and therefore could be possibly accounted for by the highest concentrations mentioned above for the marine source of ${ }^{210} \mathrm{Po}$. However, it can be pointed out in Figure $1 d$ that there is at least one case which is an exception to this interpretation $\left({ }^{210} \mathrm{~Pb}=1.4 \times 10^{-15} \mathrm{Ci} / \mathrm{m}^{3},{ }^{210} \mathrm{Po} /{ }^{210} \mathrm{~Pb}=1.2\right)$.

\section{ANTARCTIC ATMOSPHERE}

Lead 210 concentrations measured at Dumont-Durville $\left(67^{\circ} \mathrm{S}\right.$, antarctic coast of Terre Adelie) are shown in Figure 2 together with different figures of the ${ }^{210} \mathrm{Po} /{ }^{210} \mathrm{~Pb}$ ratio (original data will be published later as a Terres Australes et Antarctiques Françaises report). The concentrations of ${ }^{210} \mathrm{~Pb}$ are clearly higher here than at Kerguelen Island. Moreover, it can be seen (for instance in Figures $2 d$ ) that overequilibriums $\left({ }^{210} \mathrm{Po} /{ }^{210} \mathrm{~Pb}>1\right)$ are compatible with ${ }^{210} \mathrm{~Pb}$ concentrations superior to $1 \times 10^{-15} \mathrm{Ci} / \mathrm{m}^{3}$. In particular from March 1965 to June 1976, 21 cases of ${ }^{210}$ Po concentrations between 2 and $8 \times$ $10^{-15} \mathrm{Ci} / \mathrm{m}^{3}$ have been recorded, for which the ${ }^{210} \mathrm{Po} /{ }^{210} \mathrm{~Pb}$ ratio was between 2.7 and 7.4 in $50 \%$ of the cases (reaching even in one case 18.1). According to the preceding considerations, such results cannot be explained by the marine source of ${ }^{210} \mathrm{Po}$ aerosols.

\section{VOLCANIC EMISSIONS OF ${ }^{210} \mathrm{PO}$}

Evidence for the presence of highly enriched volatile elements in volcanic emissions has been published by several authors either during normally active phenomena or during the violent volcanic paroxysms [Duce et al., 1975; Mroz and Zoller, 1975; Lepel et al., 1978; Buat-Menard and Arnold, 1978].

High concentrations of ${ }^{210} \mathrm{~Pb}$, aerosols $\left(1200 \times 10^{-15}\right.$ to $22,500 \times 10^{-15} \mathrm{Ci} / \mathrm{m}^{3}$ ) have been measured in the plumes of several volcanoes [Lambert et al., 1976, 1979; Polian and Lambert, 1979]. As shown in Table 1, these aerosols are very enriched in volatile elements with respect to the radioactive equilibrium: ${ }^{210} \mathrm{Bi} /{ }^{210} \mathrm{~Pb}$ was found to be between 3 and 12 and ${ }^{210} \mathrm{Po} /{ }^{210} \mathrm{~Pb}$ between 9 and 40 . These enrichments, depending on the elements properties, are controlled by several volcanic parameters including the magma temperature. $\mathrm{V} i$ lenskiy [1977] has confirmed these results by analyzing the ${ }^{210} \mathrm{Po} /{ }^{210} \mathrm{~Pb}$ ratio in ashes and condensates of the Tolbachik eruption.

The airflow from the Etna crater has been calculated by Haulet et al. [1977] by comparing the $\mathrm{SO}_{2}$ concentration in the plume and the total $\mathrm{SO}_{2}$ output and found to be $3 \times 10^{11}$ $\mathrm{m}^{3} / \mathrm{d}$. This result enables us to calculate for Etna volcano an output of $200 \mathrm{Ci} / \mathrm{yr}$ for ${ }^{210} \mathrm{~Pb}$ and $2500 \mathrm{Ci} / \mathrm{yr}$ for ${ }^{210} \mathrm{Po}$.

The discharge of ${ }^{210} \mathrm{Po}$ and ${ }^{210} \mathrm{~Pb}$ from Mount Erebus has been evaluated by Polian and Lambert [1979], by a less precise
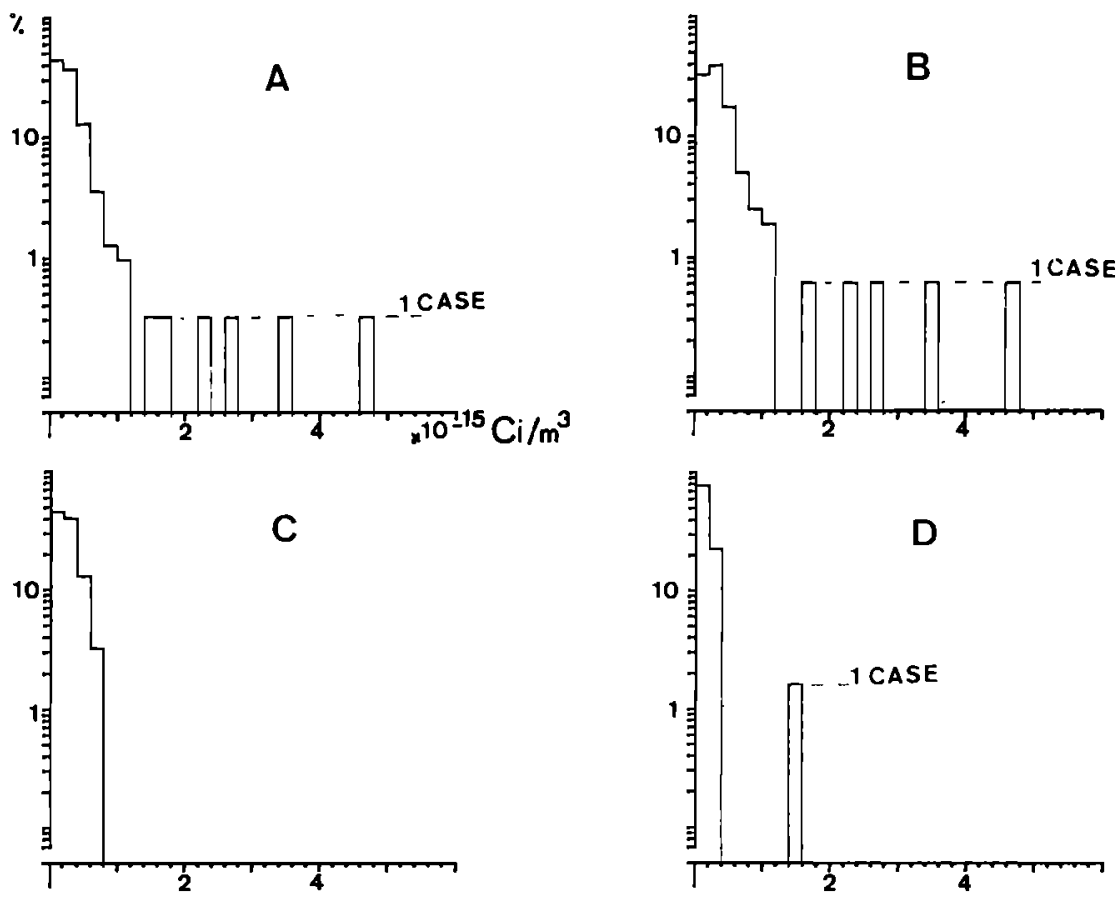

Fig. 1. Histogram of the ${ }^{210} \mathrm{~Pb}$ atmospheric concentrations observed at Kerguelen Island for different figures of the ${ }^{210} \mathrm{Po} /{ }^{210} \mathrm{~Pb}$ activity ratio. (a) All data obtained. (b) ${ }^{210} \mathrm{Po} /{ }^{310} \mathrm{~Pb}<0.5$. (c) $0.5<{ }^{210} \mathrm{Po} /{ }^{10} \mathrm{~Pb}<1$. (d) ${ }^{210} \mathrm{Po} /{ }^{210} \mathrm{~Pb}>1$. 

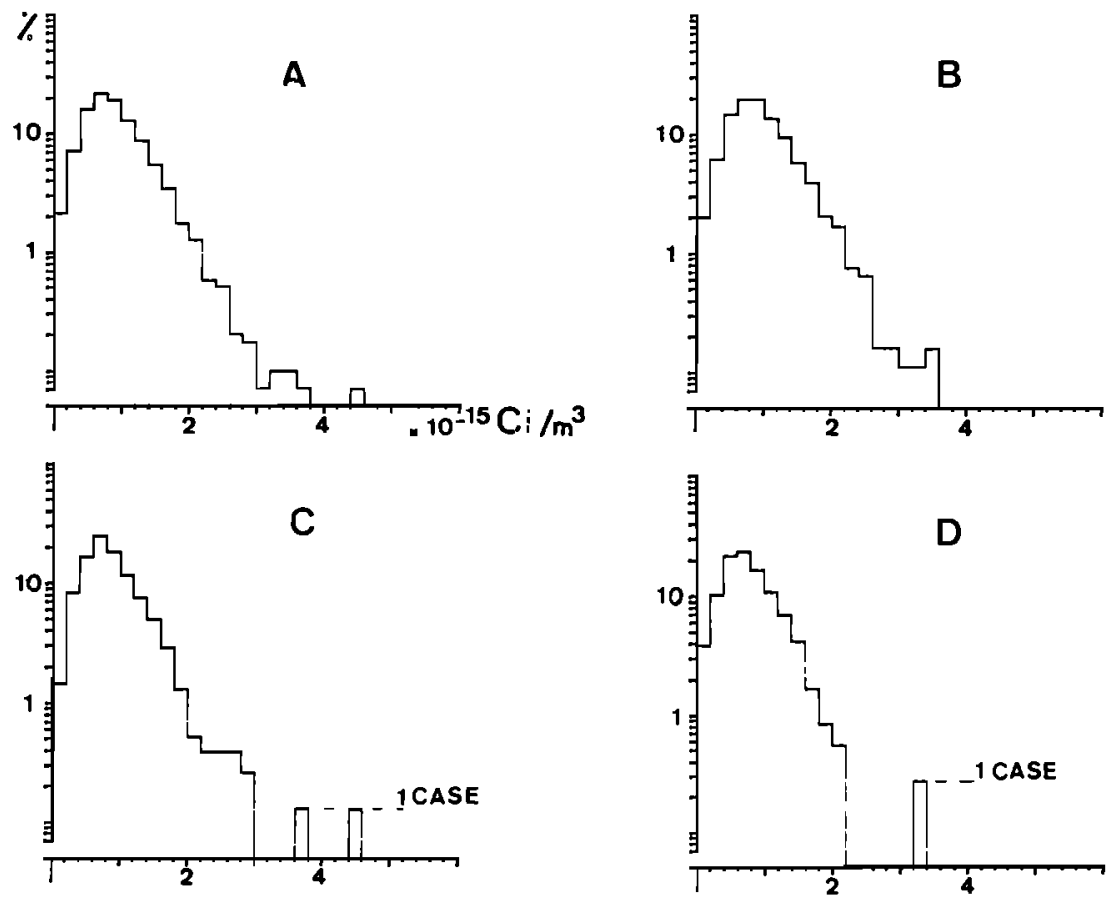

Fig. 2. Histogram of the ${ }^{210} \mathrm{~Pb}$ atmospheric concentrations observed at Terre Adelie for different figures of the ${ }^{210} \mathrm{Po} /$ ${ }^{210} \mathrm{~Pb}$ activity ratio. (a) All data obtained. (b) ${ }^{210} \mathrm{Po} /{ }^{210} \mathrm{~Pb}<0.5$. (c) $0.5<{ }^{210} \mathrm{Po} /{ }^{210} \mathrm{~Pb}<1$. (d) ${ }^{210} \mathrm{Po} /{ }^{210} \mathrm{~Pb}>1$.

method, and found to be $3 \mathrm{Ci} / \mathrm{yr}$ for ${ }^{210} \mathrm{~Pb}$ and $100 \mathrm{Ci} / \mathrm{yr}$ for ${ }^{210}$ Po.

A direct estimation of the global output of volcanic ${ }^{210} \mathrm{~Pb}$ and ${ }^{210} \mathrm{Po}$ is not possible at the present time. However, a comparison between these nuclides and the volcanic $\mathrm{SO}_{2}$ can give a good order of magnitude of this output estimate.

The only known values of the ratios ${ }^{210} \mathrm{~Pb}$ and ${ }^{210} \mathrm{Po}$ to $\mathrm{SO}_{2}$ are given in Table 2.

It is necessary to point out that the Etna plume is exceptionally rich in sulfur compounds and the Erebus plume exceptionally rich in ${ }^{210} \mathrm{~Pb}$ and ${ }^{210} \mathrm{Po}$ relative to sulfur. Consequently, the following ranges seem to be more realistic: ${ }^{210} \mathrm{~Pb}$ from $4 \times 10^{-4}$ to $1 \times 10^{-3} \mathrm{Ci} /$ ton of $\mathrm{SO}_{2}$ and ${ }^{210} \mathrm{Po}$ from $5 \times 10^{-3}$ to $4 \times 10^{-2} \mathrm{Ci} /$ ton of $\mathrm{SO}_{2}$.

Stoiber and Jepsen [1973] have estimated the total volcanic production of $\mathrm{SO}_{2}$ to be $1 \times 10^{7}$ tons/yr. The volcanic production of ${ }^{210} \mathrm{~Pb}$ is therefore comprised between $4 \times 10^{3}$ and $10 \times$ $10^{3} \mathrm{Ci} / \mathrm{yr}$, i.e., $1.4 \times 10^{23}$ to $3.5 \times 10^{23}$ atoms per year and of ${ }^{210} \mathrm{Po}$ between $50 \times 10^{3}$ and $400 \times 10^{3} \mathrm{Ci} / \mathrm{yr}$, i.e., $3.2 \times 10^{22}$ to $25 \times 10^{23}$ atoms per year.
As a comparison, the mean flux of ${ }^{222} \mathrm{Rn}$ to the atmosphere is about 1 atom $/ \mathrm{cm}^{2}$ (of continent) per second [Israel, 1951; Servant, 1964; Turekian et al., 1977], i.e., $5.2 \times 10^{25}$ atoms per year corresponding to a production of a number equivalent of ${ }^{210} \mathrm{~Pb}$ atoms, i.e., $1.5 \times 10^{6} \mathrm{Ci}$ of ${ }^{210} \mathrm{~Pb}$ per year for the whole earth. That represents from 150 to 400 times the volcanic production.

The atmospheric production of ${ }^{210} \mathrm{Po}$ can be estimated by two different ways:

1. A good mean value of the atmospheric activity of ${ }^{210} \mathrm{~Pb}$ is about $10 \times 10^{-15} \mathrm{Ci} / \mathrm{kg}$ [Sanak et al., 1978] which corresponds to $50 \times 10^{3} \mathrm{Ci}$ of ${ }^{210} \mathrm{~Pb}$ in the total atmosphere.

The atmospheric production of ${ }^{210} \mathrm{Bi}$ is therefore $5.5 \times 10^{22}$ atoms/yr.

The residence times of the aerosols marked by this 5-day half-life nuclide being of the order of 5-10 days, at least one quarter of the ${ }^{210} \mathrm{Bi}$ atoms are removed from the atmosphere and the atmospheric production of ${ }^{210} \mathrm{Po}$ is about $4 \times 10^{22}$ atoms/yr, i.e., $6 \times 10^{4} \mathrm{Ci} / \mathrm{yr}$.

2. Let $N_{\mathrm{Pb}}$ and $N_{\mathrm{Po}}$ be the total number of ${ }^{210} \mathrm{~Pb}$ and ${ }^{210} \mathrm{Po}$

TABLE 1. Volcanic Emissions of Long-Lived Radon Daughters

\begin{tabular}{|c|c|c|c|c|c|}
\hline Site and date & $\begin{array}{c}{ }^{210} \mathrm{~Pb} \\
\text { Concentration, } \\
10^{-15} \mathrm{Ci} / \mathrm{m}^{3}\end{array}$ & $\begin{array}{c}{ }^{210} \mathrm{~Pb} \\
\text { Output, } \\
\mathrm{Ci} / \mathrm{yr}\end{array}$ & $\begin{array}{c}\text { Ratio of } \\
{ }^{210} \mathrm{Bi} \\
\text { to }{ }^{210} \mathrm{~Pb}\end{array}$ & $\begin{array}{l}\text { Ratio of } \\
{ }^{210} \mathrm{Po} \\
\text { to }{ }^{210} \mathrm{~Pb}\end{array}$ & Reference \\
\hline \multicolumn{6}{|l|}{ Plume aerosols } \\
\hline Etna, June 1976 (Sicily) & $1,200-3,500$ & 200 & 5.5 & 12.5 & Lambert et al. [1979] \\
\hline Etna, June 1978 (Sicily) & $1,200-22,500$ & nd & 3 & 9 & Lambert et al. [1979] \\
\hline Stromboli, Nov. 1978 (Italy) & $1,700-2,500$ & nd & 7 & 40 & Lambert et al. [1979] \\
\hline Erebus, Jan. 1978 (Antarctic) & $3,800-12,100$ & 3 & 10.2 & 31 & Lambert et al. [1979] \\
\hline Merapi, Aug. 1978 (Indonesia) & 600 & nd & 11 & 24 & Lambert et al. [1979] \\
\hline \multicolumn{6}{|l|}{ Tolbachik, Aug. 1979 (Kamchatka) } \\
\hline Ashes & & & & 17 & Vilenskiy [1977] \\
\hline Condensate & & & & 18 & Vilenskiy [1977] \\
\hline Ambient atmosphere & 10 & & $\sim 1$ & 0.1 & \\
\hline
\end{tabular}

nd, not determined. 
TABLE 2. Annual Output of Volcanic Products

\begin{tabular}{lccccc}
\hline & $\begin{array}{c}\mathrm{SO}_{2}, \\
\text { tons/yr }\end{array}$ & $\begin{array}{c}{ }^{210} \mathrm{~Pb}, \\
\mathrm{Ci} / \mathrm{yr}\end{array}$ & $\begin{array}{c}{ }^{210} \mathrm{Po}, \\
\mathrm{Ci} / \mathrm{yr}\end{array}$ & $\begin{array}{c}{ }^{210} \mathrm{~Pb} / \mathrm{SO}_{2}, \\
\mathrm{Ci} / \text { ton }\end{array}$ & $\begin{array}{c}{ }^{210} \mathrm{Po} / \mathrm{SO}_{2} \\
\mathrm{Ci} / \mathrm{ton}\end{array}$ \\
\hline Etna & $1 \times 10^{6 *}$ & $200 \dagger$ & $2500 \dagger$ & $2 \times 10^{-4}$ & $2.5 \times 10^{-3}$ \\
Erebus & $1.2 \times 10^{3} \ddagger$ & $3 \ddagger$ & $100 \ddagger$ & $2.5 \times 10^{-3}$ & $8.3 \times 10^{-2}$ \\
\hline
\end{tabular}

* Haulet et al. [1977].

†Lambert et al. [1979].

$\ddagger$ Polian and Lambert [1979].

atoms in the atmosphere, $\phi_{\mathrm{Pb}}$ and $\phi_{\mathrm{Po}}$ the flux per time unit of those atoms to the atmosphere.

Admitting that the residence times of lead and polonium aerosols are the same, a steady state is characterized by

$$
\begin{aligned}
& \phi_{\mathrm{Pb}}=\left(\lambda_{\mathrm{Pb}}+\lambda_{s}\right) N_{\mathrm{Pb}} \simeq \lambda_{s} N_{\mathrm{Pb}} \\
& \phi_{\mathrm{Po}}=\left(\lambda_{\mathrm{Po}}+\lambda_{s}\right) N_{\mathrm{Po}} \simeq \lambda_{s} N_{\mathrm{Po}}
\end{aligned}
$$

or, by using radioactivity units:

$$
\frac{\left(\lambda_{\mathrm{Po}} \phi_{\mathrm{Po}}\right)}{\left(\lambda_{\mathrm{Pb}} \phi_{\mathrm{Pb}}\right)}=\frac{\lambda_{\mathrm{Po}} N_{\mathrm{Po}}}{\lambda_{\mathrm{Pb}} N_{\mathrm{Pb}}}
$$

which is equal to the activity ratio ${ }^{210} \mathrm{Po} /{ }^{210} \mathrm{~Pb}$, i.e., 0.1 in the most important part of the atmosphere [Lambert and Nezani, 1965; Moore et al., 1973].

Therefore the total flux of ${ }^{210} \mathrm{Po}$ to the atmosphere from all kinds of sources should be $1 / 10$ of that of ${ }^{210} \mathrm{~Pb}$, i.e., $1.5 \times 10^{5}$

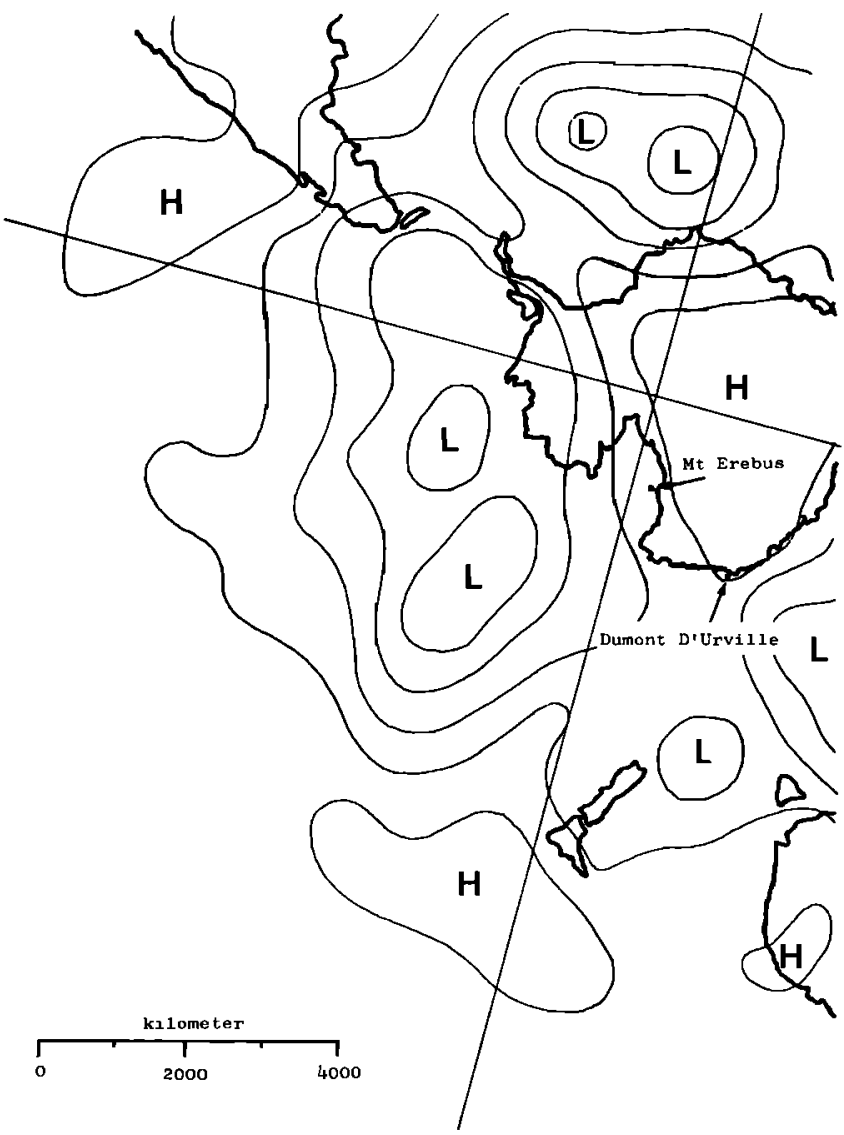

Fig. 3. Meteorological situation on May 4, 1973. ${ }^{210} \mathrm{Po}=2.28$ $10^{-15} \mathrm{Ci} / \mathrm{m}^{3},{ }^{210} \mathrm{~Pb}=0.8410^{-15} \mathrm{Ci} / \mathrm{m}^{3}$, and ${ }^{210} \mathrm{Po} /{ }^{210} \mathrm{~Pb}=2.72$.
$\mathrm{Ci} / \mathrm{yr}$, or $1 \times 10^{23}$ atoms per year. This is of the same order of magnitude as the calculated volcanic source.

As a conclusion, we can ascertain that the volcanic emission of ${ }^{210} \mathrm{Po}$ is equal, or superior, to its production in the atmosphere by the ${ }^{210} \mathrm{~Pb}$ disintegration. On the other hand, the volcanic ${ }^{210} \mathrm{~Pb}$ is generally negligible with respect to the continental production, except perhaps in some very limited areas or during exceptionally strong volcanic events. It is worthwhile to recall that a similar conclusion was drawn by Polian and Lambert [1979] for the Erebus volcano and the antarctic continent.

Therefore it has been possible to connect the observation of overequilibrium ${ }^{210} \mathrm{Po} /{ }^{210} \mathrm{~Pb}$ at Durmont-Durville (Terre Adelie) to meteorological conditions in which air masses could go directly from Mount Erebus to this part of the antarctic coast, as shown in Figure 3.

\section{Lead AND Polonium 210 In The StRatosPhere}

The first measurement of lead and polonium 210 in the stratosphere was made by Burton and Stewart [1960] by means of aircraft sampling. Later a large number of measures were made by several authors, but the main series of results have been published by Peirson et al. [1966], Moore et al. [1973], and Krey [1975].

Most of these results give a ${ }^{210} \mathrm{Po} /{ }^{210} \mathrm{~Pb}$ activity ratio between 0.6 and 1.0. However, Krey [1975] obtained between 1 and 2 in $6 \%$ of the cases (85 among 1300) and in $40 \%$ of the high-altitude balloon-borne sampling. The validity of such results has been questioned by their author himself. It is for this reason that since 1976 four experiments have been made by balloon in the lower stratosphere, from Aire-surl'Adour (France). The aim of these experiments being to measure the ${ }^{210} \mathrm{Po} /{ }^{210} \mathrm{~Pb}$ activity ratios, special attention was paid to avoid contamination by tropospheric air during the crossing of the lower altitudes, and before the recovering of the samples. The filters, first put in the sampler, were carefully washed in place by a $\mathrm{HNO}_{3}$ solution circulation just before the flight, then enclosed between two electric tight shutters, only opened during the sampling. The collected aerosols were recovered by the same operation, always without handling of the filter.

Lead and polonium were separated, as oxides, by using a ${ }^{210} \mathrm{~Pb}$-free lead carrier. The ${ }^{210} \mathrm{Po}$ was deposited on a silver plate and measured by using a very low background $\alpha$ spectrometer. The ${ }^{210} \mathrm{~Pb}$ was determined by measuring the ${ }^{210} \mathrm{Po}$ ingrowth during a 4-5 month interval, by using the same $\alpha$ spectrometer. Each experiment included a blank submitted to the same treatment but without air filtration. The results are shown in Table 3.

It may be observed that in the case of flights 3 and 4 the samples show certainly an excess in ${ }^{210} \mathrm{Po}$ relative to equilibrium with ${ }^{210} \mathrm{~Pb}$. This is because of the existence of an independent source for the stratospheric ${ }^{210} \mathrm{Po}$. According to the 
TABLE 3. Stratospheric ${ }^{210} \mathrm{Po} /{ }^{210} \mathrm{~Pb}$ Activity Ratios

\begin{tabular}{lcccc}
\hline & Fight 1 & Flight 2 & Flight 3 & Flight 4 \\
\hline Date & Sept. 21, 1976 & May 6, 1977 & Oct. 26, 1977 & April 27, 1978 \\
Altitude, $\mathrm{km}$ & $10-12$ & 15 & 17.5 & 17 \\
${ }^{110} \mathrm{~Pb}$ concentration, $10^{-15} \mathrm{Ci} / \mathrm{kg}$ & $3.3 \pm 0.3$ & $7.0 \pm 0.7$ & $3.7 \pm 0.5$ & $4.4 \pm 0.6$ \\
Ranges for ${ }^{210} \mathrm{Po} /{ }^{210} \mathrm{~Pb}$ & $0.40 / 0.67$ & $0.74 / 1.03$ & $1.35 / 2.00$ & $1.35 / 2.02$ \\
\hline
\end{tabular}

Blank activities, corresponding to about $20 \%$ of that of the sample, are deduced.

preceding considerations the most likely source seems to be an injection of ${ }^{210}$ Po by the major volcanic explosions.

As previously made, a comparison between lead, polonium, and sulfur compounds should be very useful. In effect, according to Lepel et al. [1978] the ${ }^{210}$ Po enrichment should be particularly high during the initial phase of a volcanic explosion.

Castleman et al. [1974] concluded from the study of the stratospheric sulfur isotopic composition that volcanic emissions represent the major source of stratospheric sulfates. The major eruption of Vulcan de Fuego in October 1974 caused an enhancement of $1.6 \times 10^{6}$ tons of $\mathrm{SO}_{4}$ in the stratosphere 6 months after the eruption [Lazrus et al., 1979]. Cadle [1975] estimated that the $\mathrm{SO}_{2}$ volcanic emission rate to the stratosphere is $2.8 \times 10^{5}$ tons/yr. This latter figure should correspond to a stratospheric reservoir greater than $2 \times 10^{4}$ tons $\mathrm{SO}_{4}$, as estimated by Kritz [1975].

By using the ratios ${ }^{210} \mathrm{~Pb} / \mathrm{SO}_{2}$ and ${ }^{210} \mathrm{Po} / \mathrm{SO}_{2}$ based on Table 2 the value indicated by Cadle would mean that the ${ }^{210} \mathrm{~Pb}$ volcanic injection to the stratosphere could be between 112 and $280 \mathrm{Ci} / \mathrm{yr}$. As a comparison, the average concentration of ${ }^{210} \mathrm{~Pb}$ in the stratosphere is about $5 \times 10^{-15} \mathrm{Ci} / \mathrm{kg}$ corresponding to $3000 \mathrm{Ci}$ for the whole stratosphere. Therefore as previously pointed out for the troposphere, the volcanic source of ${ }^{210} \mathrm{~Pb}$ to the stratosphere is insignificant. On the other hand, the injection of ${ }^{210}$ Po would be from $1.4 \times 10^{3}$ to $11.2 \times 10^{3}$ $\mathrm{Ci} / \mathrm{yr}$, i.e., the same order of magnitude as the flux produced by the disintegration of the stratospheric ${ }^{210} \mathrm{~Pb}$.

Such a polonium source should be visible by analyzing the very large number of stratospheric data published by Krey [1975].

Figure 4 shows the repartition in time and latitude of the cases where a ${ }^{210}$ Po excess has been observed at altitudes higher than $15 \mathrm{~km}$, together with the main published volcanic explosions. It appears particularly clear that no ${ }^{210}$ Po excess was obtained during the quiet period from late 1968 to May 1970. But at this time, successive explosions of mounts Hekla (May 1970), Beerenberg (October 1970), and Kliuchevskoi (December 1970) were immediately followed by the reappearance of ${ }^{210}$ Po excess beginning at the same latitude as these volcanoes.

It can also be pointed out that the higher rate of volcanic explosions in the northern hemisphere than in the southern corresponds to a much more frequent appearance of ${ }^{210} \mathrm{Po}$ excess.

Unfortunately, ${ }^{210}$ Po was no longer measured by the U.S. program after 1975. However, it can be seen in Table 3 that a systematic difference seems to exist between the experiment relative to 1976 and the results obtained after May 1977 where we found an overequilibrium. This difference has been tentatively attributed to the violent explosion of Mount Niragongo, January 10, 1977.

The results of the flights 3 and 4 would need a stratospheric injection of at least $1 \times 10^{3} \mathrm{Ci}$ of ${ }^{210} \mathrm{Po}$.

It is very difficult to determine whether such an amount of
${ }^{210}$ Po could have been injected into the stratosphere by this volcanic explosion. In effect, according to Tazieff [1977] the volume of lavas spilled out has been estimated at 20 to $22 \times$ $10^{6} \mathrm{~m}^{3}$ but after the eruption the increase of the crater volume was measured to be $250 \times 10^{6} \mathrm{~m}^{3}$, i.e., 10 times more. Moreover, we have no information at all on a possible ${ }^{210}$ Po enrichment of the magmatic gases responsible for the explosion.

It can be questioned whether the changes in nature of stratospheric aerosols observed early in 1977 by Gras [1978] could also be attributed to the Niragongo explosion.

The first consequence of ${ }^{210} \mathrm{Po}$ volcanic injections into the stratosphere is to strongly change the calculation of the aerosol residence time in the stratosphere.

Let $N_{\mathrm{Pb}}$ and $N_{\mathrm{Po}}$ be the total number of atoms of ${ }^{210} \mathrm{~Pb}$ and ${ }^{210} \mathrm{Po}$, respectively, in the stratosphere, $\lambda_{s}$ the scavenging constant, and $\phi_{\mathrm{Po}}$ the flux of volcanic ${ }^{210} \mathrm{Po}$ to the stratosphere.

A steady state is characterized by

$$
\lambda_{\mathrm{Pb}} N_{\mathrm{Pb}}+\phi_{\mathrm{Po}}=\left(\lambda_{\mathrm{Po}}+\lambda_{s}\right) N_{\mathrm{Po}}
$$

If $r$ is the average ratio $\lambda_{\mathrm{Po}} N_{\mathrm{Po}} / \lambda_{\mathrm{Pb}} N_{\mathrm{Pb}}$, we have

$$
\lambda_{S}=\lambda_{\mathrm{Po}}\left[\frac{1}{r}\left(1+\frac{\phi_{\mathrm{Po}}}{\lambda_{\mathrm{Pb}} N_{\mathrm{Pb}}}\right)-1\right]
$$

$\lambda_{\mathrm{Pb}} N_{\mathrm{Pb}}$ is about $3000 \mathrm{Ci}$, i.e., $6.7 \times 10^{15} \mathrm{dpm} ; \phi_{\mathrm{Po}}$ has been evaluated to be at least $1000 \mathrm{Ci} / \mathrm{yr}$, i.e., $1.3 \times 10^{15}$ atoms $/ \mathrm{min}$ in the case of a steady state; $r$ is measured to be of the order of 0.8 .

We find thus $\lambda_{s}=0.5 \lambda_{\mathrm{P}_{\mathrm{O}}}$ corresponding to a half life of 276 $\mathrm{d}$, which should be a maximum value (instead of $1.5 \mathrm{yr}$ if $\phi_{\mathrm{Po}}$ $=0$ ).

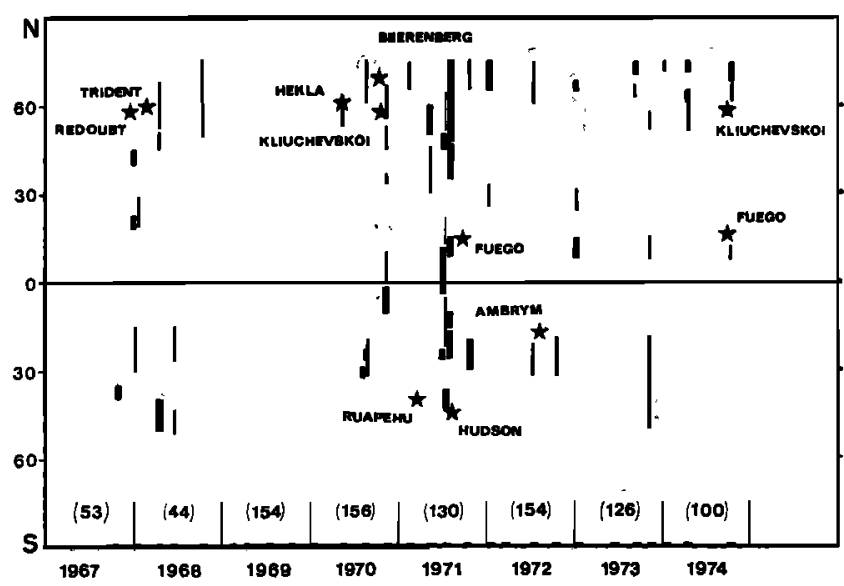

Fig. 4. Time and latitudinal repartition of ${ }^{210} \mathrm{Po} /{ }^{210} \mathrm{~Pb}$ overequilibriums measured by $K r e y$ [1975] at altitudes greater than $15 \mathrm{~km}$. Thin lines indicate $1<{ }^{210} \mathrm{Po} /{ }^{210} \mathrm{~Pb}<1.2$, heavy lines indicate ${ }^{210} \mathrm{Po} /$ ${ }_{210} \mathrm{~Pb}>1.2$, stars represent the major volcanic explosion reported, able to give stratospheric injection. Numbers in parentheses indicate sample numbers during the year. 


\section{CONCLUSION}

Owing to the scavenging processes, the residence time of the aerosols in the troposphere is much too short to allow ${ }^{210} \mathrm{~Pb}$ and ${ }^{210} \mathrm{Po}$ to reach radioactive equilibrium with ${ }^{222} \mathrm{Rn}$. Consequently, the flux from the soil to the whole atmosphere which is $3 \times 10^{9} \mathrm{Ci} / \mathrm{yr}$ for ${ }^{222} \mathrm{Rn}$ yielding by radioactive decay $1.5 \times 10^{6} \mathrm{Ci} / \mathrm{yr}$ for ${ }^{210} \mathrm{~Pb}$, and corresponds to a steady state production of $6 \times 10^{4} \mathrm{Ci} / \mathrm{yr}$, for ${ }^{210} \mathrm{Po}$.

This explains why the existence of volcanic sources may be completely negligible on a global scale in the case of ${ }^{222} \mathbf{R} n$, very weak for ${ }^{210} \mathrm{~Pb}$, but quite significant for ${ }^{210} \mathrm{Po}$, especially as this last nuclide is very enriched, relative to ${ }^{210} \mathrm{~Pb}$, in all of the volcanic plumes that we have studied. The volcanic ${ }^{210} \mathrm{Po}$ production of $5 \times 10^{4} \mathrm{Ci} / \mathrm{yr}$, indicated in this work, is thus equivalent to the production by the disintegration of the ${ }^{210} \mathrm{~Pb}$ present in the atmosphere. Such a value, which represents about 20 times the production by Mount Etna only, accounts for a mean ${ }^{210} \mathrm{Po} /{ }^{210} \mathrm{~Pb}$ activity ratio greater than 0.1 , and therefore higher than the figure expected from theoretical calculations based on the aerosol residence time as established from other pairs of nuclides.

The existence of this significant volcanic source of ${ }^{210} \mathrm{Po}$ also accounts for the frequent observations of ${ }^{210} \mathrm{Po} /{ }^{210} \mathrm{~Pb}$ activity ratios greater than 1 , which seem generally impossible to attribute to the other ${ }^{210} \mathrm{Po}$ sources considered: a marine source of ${ }^{210} \mathrm{Po}$ is very likely but should be too weak to be significant, except perhaps when the ${ }^{210} \mathrm{~Pb}$ concentration is extremely low.

The high ${ }^{210} \mathrm{Po}$ concentration in the Mount Erebus emissions is probably responsible for the observation of very high ${ }^{210} \mathrm{Po} /{ }^{210} \mathrm{Po}$ ratios in Terre Adelie.

Volcanic emissions of ${ }^{210} \mathrm{Po}$ reach the stratosphere and there modify significantly the ${ }^{210} \mathrm{Po} /{ }^{210} \mathrm{Po}$ ratio for several months after the injection. However, the relatively high frequency of overequilibrium observations, only can be explained by these injections from volcanoes.

One of the consequences of these volcanic injections into the stratosphere is to change the calculation of the aerosol half-life in this reservoir. The figures indicated in this work, about 280 days, is shorter than the values initially admitted but in good agreement with the last results published by Moore, Poet, and Martell. However, a systematic study of ${ }^{210} \mathrm{Po} /{ }^{210} \mathrm{~Pb}$ ratios in the stratosphere should be continued, possibly in connection with major volcanic eruptions.

Acknowledgments. This work has been supported by the French Centre National d'Etudes Spatiales, Délégation Générale à la Recherche Scientifique et Technique and Terres Australes et Antarctiques Françaises. The authors are very grateful to A. Jegou, to the balloon launching team at Aire sur l'Adour, to Expéditions Polaires Françaises, and K. K. Turekian for useful suggestions.

\section{REFERENCES}

Bacon, M. P., D. W. Spencer, and P. G. Brewer, ${ }^{210} \mathrm{~Pb} /{ }^{226} \mathrm{Ra}$ and ${ }^{210} \mathrm{Po} /{ }^{210} \mathrm{~Pb}$ disequilibria in seawater and suspended particulate matter, Earth Planet. Sci. Lett., 32, 277-296, 1976.

Barger, W. R., and W. D. Garrett, Surface active organic material in the marine atmosphere, J. Geophys. Res., 75, 4561-4566, 1970.

Beasly, T. M., Polonium-210, lead-210 and stable lead in marine organisms, $H A S L-273$, pp. 12-37, U.S. At. Energy Comm., April 1, 1973.

Buat-Ménard, P., and M. Arnold, The heavy metal chemistry of atmospheric particulate matter emitted by Mount Etna volcano, Geophys. Res. Lett., 5, 245-248, 1978.

Burton, R. D., and N. G. Stewart, Use of long-lived natural radioactivity as an atmospheric tracer, Nature, 186, 584-589, 1960.
Cadle, R. D., Volcanic emissions of halides and sulfur compounds to the troposphere and stratosphere, J. Geophys. Res., 80, 1650-1652, 1975.

Castleman, A. W., H. R. Munkelwitz, and B. Manowitz, Isotopic studies of the sulfur component of the stratospheric aerosol layer, Tellus, 26, 222-234, 1974.

Duce, R. A., G. L. Hoffman, and W. H. Zoller, Atmospheric trace metals at remote northern and southern hemisphere sites: Pollution or natural?, Science, 187, 59-61, 1975.

Gras, J. L., Change in nature of stratospheric aerosols collected at $34^{\circ} \mathrm{S}$, Nature, $271,231-232,1978$.

Haulet, R., P. Zettwoog, and J. C. Sabroux, Sulphur dioxide discharge from Mount Etna, Nature, 268, 715-717, 1977.

Hoffman, E. J., and R. A. Duce, Organic carbon in marine atmosphere particulate matter: Concentration and particule size distribution, Geophys. Res. Lett., 4, 449-452, 1977.

Israel, H., Radioactivity of the atmosphere, in Compendium of Meteorology, edited by T. F. Malone, pp. 155-161, American Meteorological Society, Boston, 1951.

Jacobi, W., and K. Andre, The vertical distribution of radon-222, radon-220, and their decay products in the atmosphere, $J$. Geophys. Res., 68, 3799-3814, 1963.

Karol, I. L., Calculation of planetary distributions of radon and its long-lived daughter concentrations in the troposphere and lower stratosphere, Tellus, 22, 219-227, 1970.

Krey, P. W., Project airstream, USAEC Rep. HASL-297, Oct. 1975.

Kritz, M., An advective hypothesis for the formation of the stratospheric aerosol layer, J. Phys., Supplement, 36, C8-17, 1975.

Lambert, G., and $M$. Nezami, Importance des retombées sèches dans le bilan du plomb 210, Ann. Geophys., 2I(2), 245-250, 1965.

Lambert, G., and G. Polian, Sur la diffusion à basse altitude des masses d'air continentales et océaniques dans chaque hémisphère, C. $R$. Acad. Sci. Paris, 256, 4265-4267, 1963.

Lambert, G., B. Ardouin, M. Nezami, and G. Polian, Possibilities of using lead 210 as an atmospheric tracer, Tellus, 18, 421-426, 1966.

Lambert, G., B. Ardouin, G. Polian, and J. Sanak, Natural radioactivity balance in the atmosphere of the southern hemisphere, in The Natural Radiation Environment II, Houston, 1972.

Lambert, G., J. Sanak, and B. Ardouin, Origine marine des excès de polonium 210 dans la basse atmosphère antarctique, $J$. Rech. Atmos., 8, 647-648, 1974.

Lambert, G., P. Bristeau, and G. Polian, Emission and enrichments of radon daughters from Etna Volcano magma, Geophys. Res. Lett., 3, 724-726, 1976.

Lambert, G., P. Bristeau, F. Le Guern, G. Polian, and J. Sabroux, Caractérisation des gaz magmatiques et fumerolliens par leurs Aérosols radioactifs, C. R. Acad. Sci., Ser. D, 288, 743-746, 1979.

Lazrus, A. L., R. D. Cadle, B. W. Gandrud, J. P. Greenberg, B. J. Huebert, and W. I. Rose, Jr., Sulfur and halogen chemistry of the stratosphere and of volcanic eruption plumes, J. Geophys. Res., 84, in press, 1979.

Lepel, E. A., K. M. Stefansson, and W. H. Zoller, The enrichment of volatile elements in the atmosphere by volcanic activity: Augustine Volcano 1976, J. Geophys. Res., 83, 6213-6220, 1978.

Marenco, A., and J. Fontan, Sources of polonium-210 within the troposphere, Tellus, 24, 38-46, 1972.

Moore, H. E., S. E. Poet, and E. A. Martell, ${ }^{222} \mathrm{Rn},{ }^{210} \mathrm{~Pb},{ }^{210} \mathrm{Bi}$, and ${ }^{210} \mathrm{Po}$ profiles and aerosol residence times versus altitude, $J$. Geophys. Res., 78, 7065-7075, 1973.

Mroz, E. J., and W. H. Zoller, Composition of atmospheric particulate matter eruption of Heimaey, Iceland, Science, 190, 461-464, 1975.

Nozaki, Y., and S. Tsunogai, ${ }^{226} \mathrm{Ra},{ }^{210} \mathrm{~Pb}$, and ${ }^{210} \mathrm{Po}$ disequilibria in the western North Pacific, Earth Planet. Sci. Lett., 32, 313-321, 1976.

Nozaki, Y., J. Thomson, and K. K. Turekian, The distribution of ${ }^{210} \mathrm{~Pb}$ and ${ }^{210} \mathrm{Po}$ in the surface waters of the Pacific ocean, Earth Planet. Sci. Lett., 32, 304-312, 1976.

Peirson, D. H., R. S. Cambray, and G. S. Spicer, Lead 210 and polonium 210 in the the atmosphere, Tellus, 18, 428-433, 1966.

Poet, S. E., H. E. Moore, and E. A. Martell, Lead 210, bismuth 210 and polonium 210 in the atmosphere: Accurate ratio measurement and application to aerosol residence time determination, $J$. Geophys. Res., 77, 6515-6527, 1972.

Polian, G., and G. Lambert, Radon daughters and sulfur output from Erebus Volcano (Antarctica), J. Volcanics Geothermal Res., in press, 1979. 
Sanak, J., G. Lambert, and B. Ardouin, Lead 210 in the atmosphere, NRE III, Houston, in press, 1978.

Servant, J., Radon and its short-lived daughters in the lower atmosphere, Ph.D. thesis, Univ. of Paris, Paris, 1964.

Stoiber, R., and A. Jepsen, Sulfur dioxide contributions to the atmosphere by volcanoes, Science, 182, 577-578, 1973.

Tazieff, H., An exceptional eruption: Mt. Niragongo, Jan. 10th, 1977, Bull. Volcanol., 4O(3), 2-12, 1977.

Turekian, K. K., D. P. Kharkar, and J. Thomson, The fates of ${ }^{210} \mathrm{~Pb}$ and ${ }^{210}$ Po in the ocean surface, J. Rech. Atmos., 8, 639-646, 1974.
Turekian, K. K., Y. Nozaki, and L. K. Benninger, Geochemistry of atmospheric radon and radon products, Ann. Rev. Earth Planet. Sci., 5, 227-255, 1977.

Vilenskiy, V. D., Radium-226, lead-210 and polonium-210 in the products of the Tolbachik eruption in Kamchatka, Geochem. Int., 14, 14-19, 1977.

(Received April 30, 1979; revised June 13, 1979; accepted June 25, 1979.) 